\title{
Three new species of the Australian orsolobid spider genus Hickmanolobus (Araneae: Orsolobidae)
}

\author{
Barbara C. Baehr' and Helen M. Smith ${ }^{2}$ \\ 'Queensland Museum, P'O.Box 3300), South Brisbane, \\ Queensland 4101, Australia. E-mail: BarbaraB@ym.qld.govau. \\ Australian Museum, 6 College Street, Svdney, New South Wales 2010, \\ Australia. E-mail: Helen.Smith@austmus.govau
}

\begin{abstract}
Three new species of the Australian orsolobid spider genus Hickmanololus forster and Platnick 1985 are described from Queensland and New South Wales. Hickmanolobus ibisca sp. nov., Hickmanololnes jojo sp. nov: and Hickmomolobus limmeri sp. nov. are the first Hickmanolobus species to be described from the mainland of Australia.
\end{abstract}

\section{INTRODUCTION}

The tribe Orsolobini Cooke was separated from the Dysderidae by Forster and Platnick (1985), who established the family Orsolobidae. With about 180 described species in 28 genera the Orsolobidae are an important component of the forest litter fauna of the southern hemisphere (Forster and Forster 1999; Griswold and Platnick 1987; Platnick and Brescovit 1994). To date there are only four genera known from Australia. The most common Australian genus, Tasmanoonops Hickman 1930, with 29 species, occurs mainly in the wet forests of eastern Australia although two species are recorded from Western Australia. Until now the remaining three genera were monotypic: Australobus Forster and Platnick 1985 is recorded from the South West corner of Western Australia, whilst the described species of Cornifalx Hickman 1979 and Hickmanolobus Forster and Platnick 1985 are from Tasmania. Forster and Platnick mentioned that Hickmanolobus also occurred on mainland Australia but did not describe any of these species, so here we formally describe species of Hickmanolobus from the mainland of Australia for the first time.

To celebrate the tercentenary of Linnaeus' birth in 1707 and the $250^{\text {th }}$ anniversar $y$ of the publication of the Systema Naturae one of the new species of Hickmanolobus is named in honour of Carolus Linnaeus.

\section{MATERIAL AND METHODS}

Specimens were examined using a LEICA MZ16A microscope. Photomicrographic images were produced using a Leica DFC 500 and the software program AutoMontage Pro Version 5.(2) (p). Specimen parts were prepared for scanning electron microscopy by dehydration through stages of $95 \%$ and $100 \%$ ethanol and then critical point drving. SEM's were taken with a Hitachi LEO 435VP SEM using a Robinson backscatter detector. Descriptions were generated with the aid of the PBI descriptive goblin spider database and shortened where possible. The map was created with Biolink version 1.5 (CSIRO) Entomology, Canberra, Australia; http://www.biolink.csiro. au/). All measurements are in millimetres. Throughout the text, figures cited from other publications are listed as "figure", those given in this paper as "Figure".

Abbreviations used in the text and figures: ALE, anterior lateral eye(s); ECC, embolus conductor complex; PLE, posterior lateral eye(s); PME, posterior median eye(s); PBI: Planetary Biodiversity Inventory; SEM, scanning electron microscope. For specimen registration numbers, the prefix AM indicates that the specimen is deposited in the Australian Museum, Sydney; QM, ditto for the Queensland Museum, Brisbane. The specimens of Hickmanolobus mollipes (Hickman 1932) examined for comparative purposes were: 59 , Tasmania, East Risdon, 23 September 1947, V.V. Hickman (AM KS2707; this male was described by Hickman 1979); 3 \%, same data (AM KS30369).

\section{SYSTEMATICS}

\section{Family Orsolobidae Cooke 1965}

Hickmanolobus Forster and Platnick 1985

\section{Type species}

Oonopinus mollipes Hickman 1932 by original designation.

\section{Diagnosis}

Orsolubids without leg spines; tarsal organ low with three small receptor nodes, few cuticular 
lobes and no elongated receptor spine; claws evenly, strongly pectinate on both margins without lateral flanges; chelicerae with two teeth on each margin; male palpal bulb squat, embolus distal, associated with a secondary lobe covered with tiny spicules; female genitalia with a large posterior recep-taculum. The abdominal dorsum shows a purple pigmentation.

\section{Description}

Small orsolobids, total length of males c. 1.4-1.8, and females 1.7-2.2. Carapace ovoid, anteriorly broad with rounded posterolateral corners, lateral margin and clypeus rebordered, surface granulate (Figures 21-23). Clypeus slightly curved downwards in front view and slightly sloping forward in lateral view (Figures 22, 24, 11-15). Clypeus high, ALE separated from edge of carapace by more than their radius (Figures 16-20, 24). Clypeus and non marginal pars cephalica with needle-like setae (Figure 21), setae sparse or absent marginally. Chilum absent (Figure 26). Six eyes, well developed, almost equal in size. ALE oval, PME oval, PLE circular; posterior eye row recurved, from above (Figures 1-5, 21) and front view (Figures 16-20, 24). ALE-ALE separated by more than ALE diameter, ALE-PLE adjacent, PME-PME touching throughout most of their length, PLE-PME separated by less than PME radius in smaller species (eyes relatively smaller in the larger $H$. mollipes). Sternum longer than wide, not fused to carapace, surface smooth, anterior margin unmodified, posterior margin truncate, not extending posteriorly beyond base of coxa IV, with narrow extensions between coxae (Figures 6-10). Sternal setae sparse, needle-like, densest and most robust anteriorly and laterally (Figure 23). Chelicerae with two teeth on each margin. Cheliceral fang directed medially, without prominent basal process. Cheliceral setae needle-like, evenly scattered (Figure 25). Labium a truncated triangle with anterior margin indented medially, not fused to sternum. Endites about three times as long as wide, not excavated distally, curving around labium to almost meet medially, with serrula in single row, anteromedian tip and posteromedian part unmodified (Figure 26). Abdomen ovoid, dorsum dark purple with pale chevrons in posterior half (Figures 1-5; Hickman 1979 figure 5), covered with needle-like setae; book lung covers large, elliptical, without setae. Pedicel tube short, unmodified. Leg spines absent. Metatarsi I-IV with one trichobothrium positioned distally on leg I, progressively closer to mid point in legs II-IV (Figures 31-34), trichobothrium base oval with dorsal hood (Figure 27). Tarsi I-IV: claw tufts with spatulate setae (Figures 28-30). Claws evenly, strongly pectinate on both margins but without lateral flanges (Figures 39-42; Forster and
Platnick 1985 figure 327). Tarsal organ on tarsi I-IV and cymbium low with three small receptor nodes and several cuticular lobes (Figures 39-43; Forster and Platnick 1985 figures 329-330). Male palpal bulb not strongly sclerotized, cream to yellow-brown (Figures 44-52). Palpal femur more than two times as long as trochanter; patella half to two-thirds as long as femur; tibia about as long as patella; cymbium narrow in dorsal view; bulb extremely large, about three times as long as cymbium, pear-shaped; embolus conductor complex arising from invagination in apical bulb, associated retrolaterally with membranous secondary lobe covered with tiny spicules (Figures 53, 56, 59; Forster and Platnick 1985 figures 331-332). Female epigastric area with two pairs of booklung openings, epigastric fold broadly rectangular or semicircular, female internal genitalia with large posterior receptaculum (Figures 68-74; Forster and Platnick 1985 figure 244).

Characters listed above only visible clearly using SEM were not confirmed in $H$. ibisca or H. jojo. Species descriptions primarily discuss variations from the generic plan.

\section{Remarks}

Only one species, Hickmanolobus mollipes, currently belongs to this genus. The new Hickmanolobus species described here are clearly separated from $H$. mollipes by their strongly v-shaped and separated abdominal chevrons and their much shorter embolus (compare with Hickman 1979 figure 5; Forster and Platnick 1985 figure 332). The specimens were found among the oonopid collections of the Queensland Museum and the Australian Museum when sorting specimens for the "Goblin Spider PBI project". The three orsolobid species were initially misidentified as being related to Orchestina Simon 1882 due to their similar body shape. The distinctive tarsal organ and the doubly pectinate claws were seen when SEM images of $H$. Iinnaei sp. nov. were examined and it was realised that the species belonged to Hickmanolobus. The form of the palpal bulb, with a secondary lobe covered with tiny spicules, and of the female internal genitalia with large posterior receptaculum are also consistent with the characters recorded for $H$. mollipes by Forster and Platnick (1985).

\section{Key to species of Hickmanolobus}

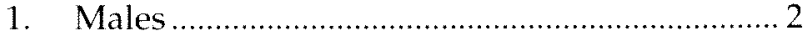

Females (unknown for $H$. jojo) 5

2. Palpal embolus long, spiniform (Forster and Platnick figure 332), anterior abdominal chevron broad and almost straight, posterior 
chevrons narrower, overlapping to form ragged stripe........H. mollipes (Hickman 1932)

Palpal embolus short, triangular (Figures 53-59), anterior chevron distinctly angular, posterior chevrons, if any, separate.............. 3

3. Carapace yellow-brown with dark purple reticulate pattern (Figure 3 ), bulb large, wider than length of cymbium and tibia combined (Figures 44-46, 53-55) ...........H. ibisca sp. nov.

Carapace yellow-brown without dark purple coloration, bulb smaller, as wide as or less than length of cymbium and tibia combined (Figures 47-52, 56-61)

4. Bulb shorter than length of cymbium and tibia combined, embolus triangular (Figures $50-52 ?, 59-61)$ H. jojo sp. nov

Bulb as wide as length of cymbium and tibia combined, embolus scooped with rounded tip (Figures 47-49?, 56-58, 65-67).

H. limnacisp. nov.

5. Anterior abdominal chevron broad and almost straight, posterior chevrons narrower, overlapping to form ragged stripe (Hickman 1979 figure 5) ........H. mollipes (Hickman 1932)

Anterior chevron distinctly angular, posterior chevrons, if any, separate (Figure 2,4)........6 6

6. Carapace with dark purple reticulate pattern, epigastric fold with posteriorly directed, $v$-shaped projection, posterior margin with rectangular sclerite, internal female genitalia with large posterior receptaculum divided into three circular compartments (Figures 69, $70,73,74)$............................... H. ibisca sp. nov.

Carapace without dark purple reticulate pattern (Figure 2), epigastric fold widely oval, posterior margin straight, internal female genitalia with elongated posterior receptaculum divided into three more triangular compartments (tapering posteriorly) (Figures 68, 71, 72).

H. linnaci sp. nov.

\section{Hickmanolobus linnaei sp. nov.}

Figures 1, 2, 6, 7, 11, 12, 16, 17, 21-43, 47-49, 68, 71, 72,75

\section{Material examined}

Holotype

Australia: New South Wales: d, Coolah Tops National Park, Breeza Lookout, 3149'17'S, $150^{\circ} 11^{\prime 2} 8^{\prime \prime} \mathrm{E}, 7-25$ November 2001, M. Gray, G. Milledge, H. Smith, pitfall trap (AM KS103319, PBI_OON_00023085).
Allotype

Australia: New South Wales: \&, same locality as holotype (AM KS103320, PBI_OON_00023212).

\section{Other materinl examined}

Australia: New South Wales: 8 o, 1 \&, same locality as holotype (AM KS75419, PBI_OON 00020291).

\section{Diagnosis}

Males resemble those of $H$. jojo but the male palpal bulb is bigger, width of bulb (measured basally) is equal to cymbium and tibia combined (Figure 47); the embolus conductor complex is wider than in $H$. jojo. Females can be separated from $H$. mollipes and $H$. ibisca by the abdominal colour pattern (female of $H$. jojo unknown); internal genitalia with posterior receptaculum tapering posteriorly to a rounded point.

\section{Description}

Male

Total length 1.43. Carapace $0.70 \mathrm{long}, 0.54$ wide, caput width 0.30 ; abdomen 0.73 long, 0.52 wide. Carapace dark yellow-brown, sternum, chelicerae, endites and labium yellow-brown. Abdominal dorsum dark purple with four pale, inverted $v$-shaped chevrons; venter centrally pale, margin dark purple (Figures 1, 6). Legs yellow-brown. Palpal bulb (Figures 47-49, 56-58, 62-67) pearshaped, basally as wide as tibia and cymbium length combined; embolus a small, curved scoop, secondary lobe rounded, medium sized, covered with tiny spicules.

\section{Female}

Total length 1.78. Carapace 0.71 long, 0.55 wide, caput width 0.32 ; abdomen 1.07 long, 0.79 wide. Coloration as in male (Figures 1-6). Epigastric fold (Figures 68, 71, 72) anteriorly broadly oval, posterior margin straight, without special features, internal female genitalia with elongated posterior receptaculum divided into three long compartments, tapering posteriorly to a rounded point. Tracheal system consisting of two simple tubes directed forward through the pedicel (Figure 72).

\section{Distribution}

This species is only known from Coolah Tops National Park in northern New South Wales (Figure 75)

\section{Etymology}

The specific name is a patronym in honour of Carolus Linnaeus who published Systema Natura in 1758 . 


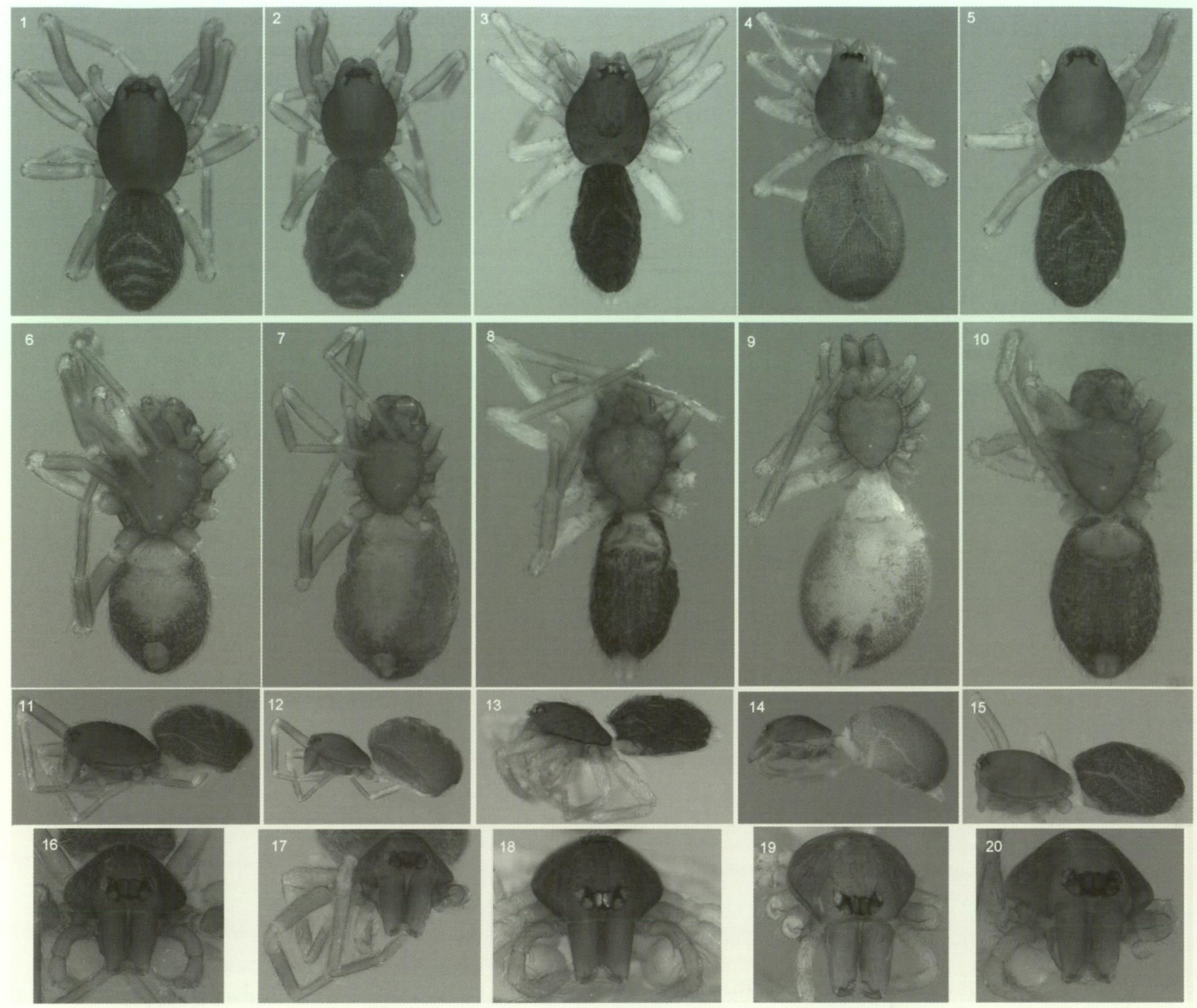

Figures 1-20 Hickmanolobus habitus: 1-5, dorsal view; 6-10, ventral view; 11-15, lateral view; 16-20, frontal view. 1, 6, 11, 16: H. linnaei ơ; 2, 7, 12, 17: H. linnaei + ; 3, 8, 13, 18: H. ibisca o ; 4, 9, 14, 19: H.ibisca + ; 5, 10, 15, 20: H. jojo o.
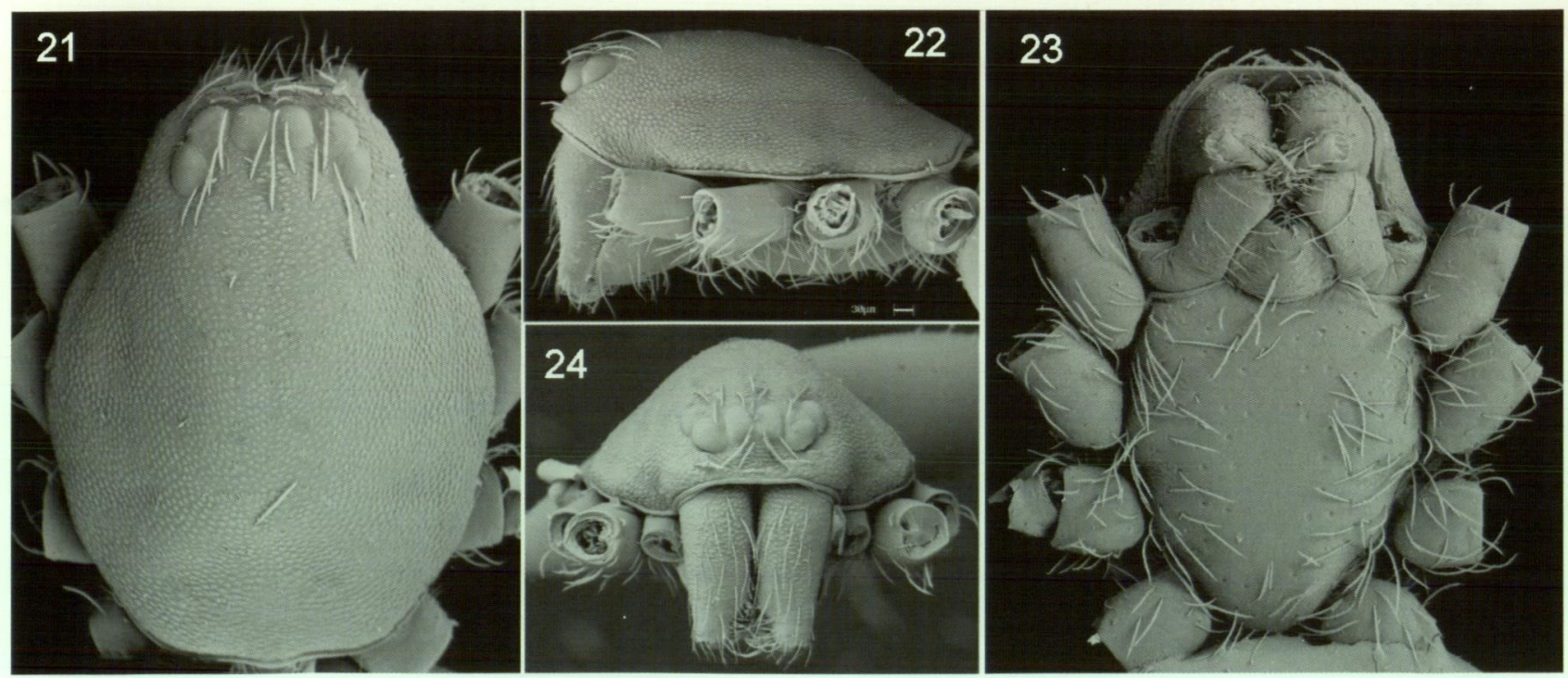

Figures 21-24 Hickmanolobus linnaei sp. nov., male, Carapace: 21, dorsal, 22, lateral; 23, ventral; 24, frontal view. 

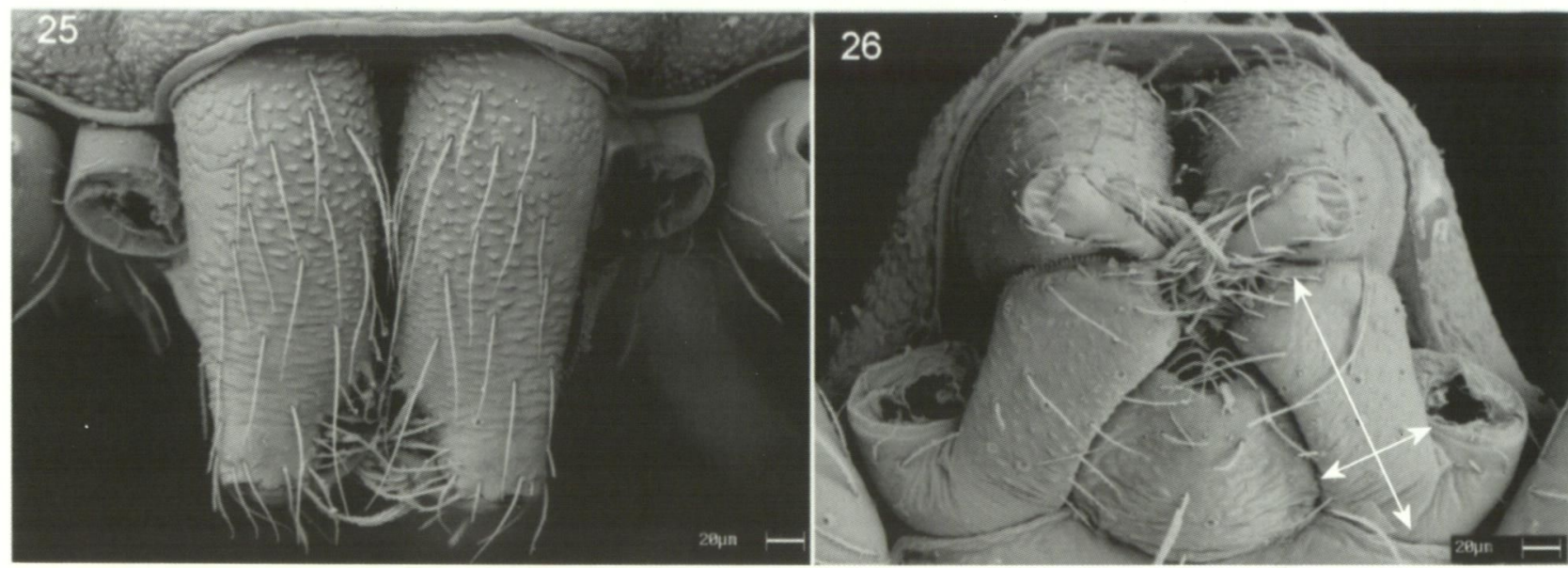

Figures 25, 26 Hickmanolobus linnaei sp. nov., male Mouthparts: 25, chelicerae, frontal; 26, endites, labium, ventral.
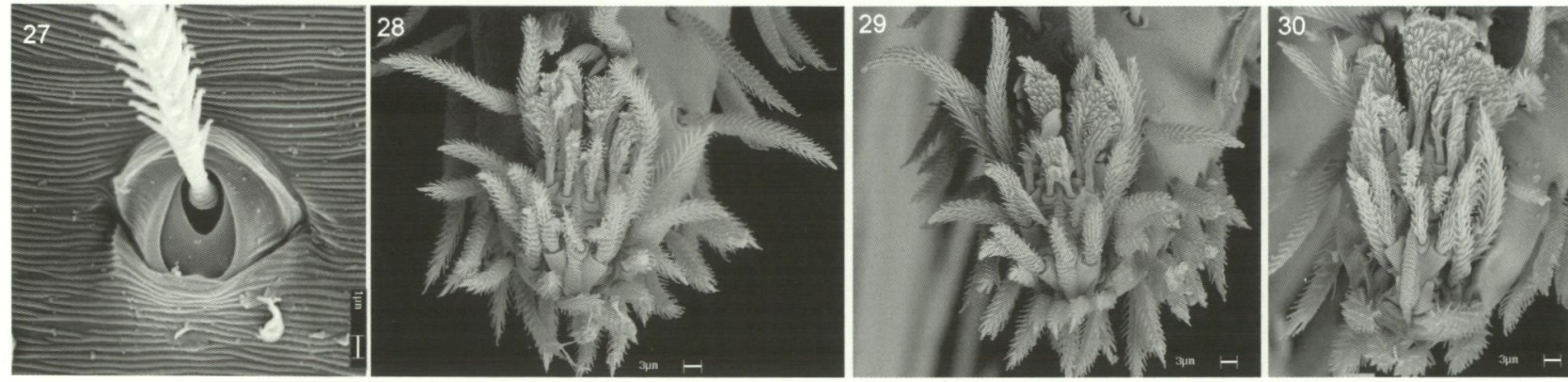

Figures 27-30 Hickmanolobus linnaei sp. nov., male: 27, trichobothrial base, metatarsus I; 28-30, claw tafts ventral: 28, leg I; 29, leg II; 30, leg IV.
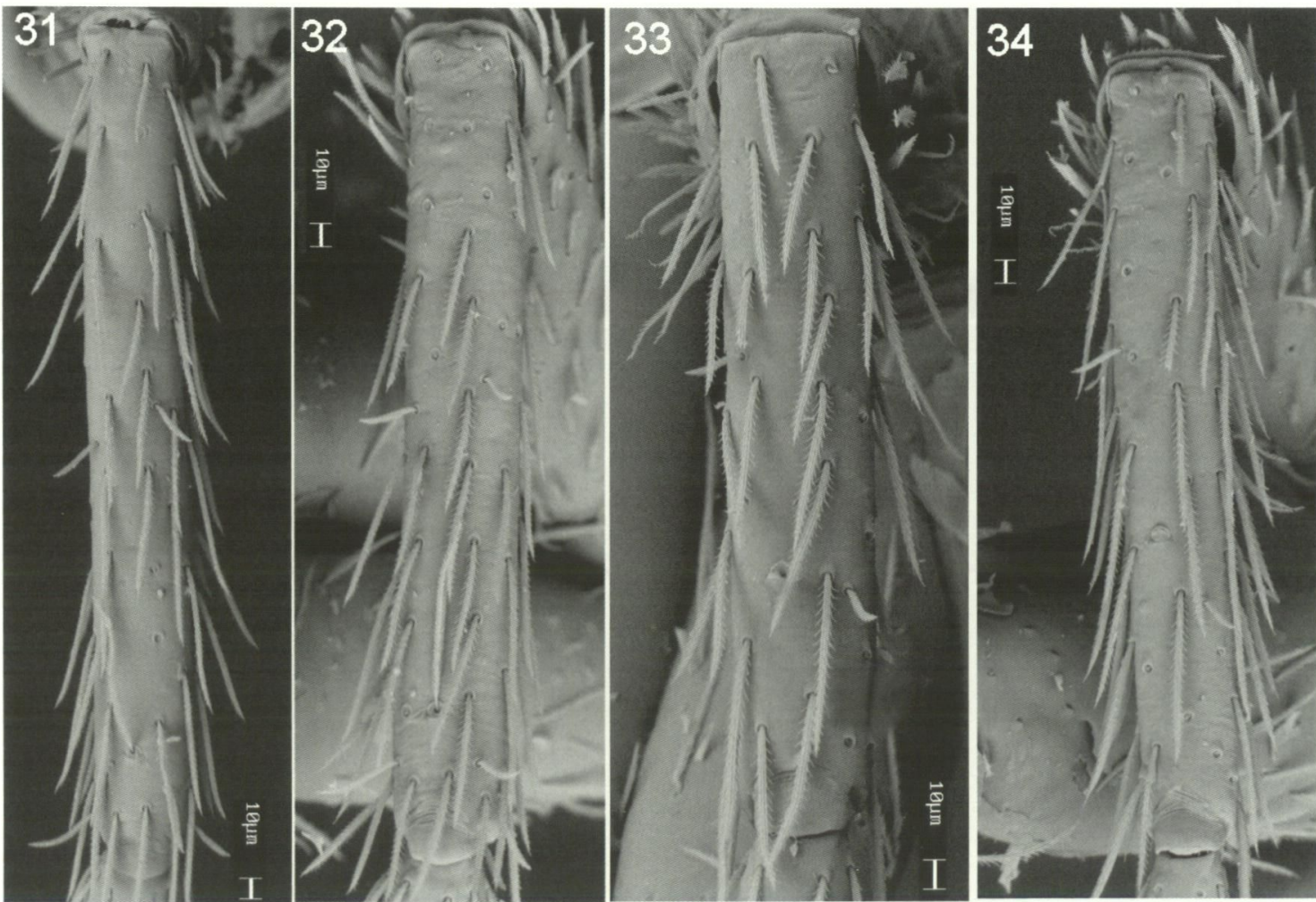

Figures 31-34 Hickmanolobus linnaei sp. nov., male, metatarsi I-IV: 31, leg I; 32, leg II; 33, leg III; 34, leg IV. 

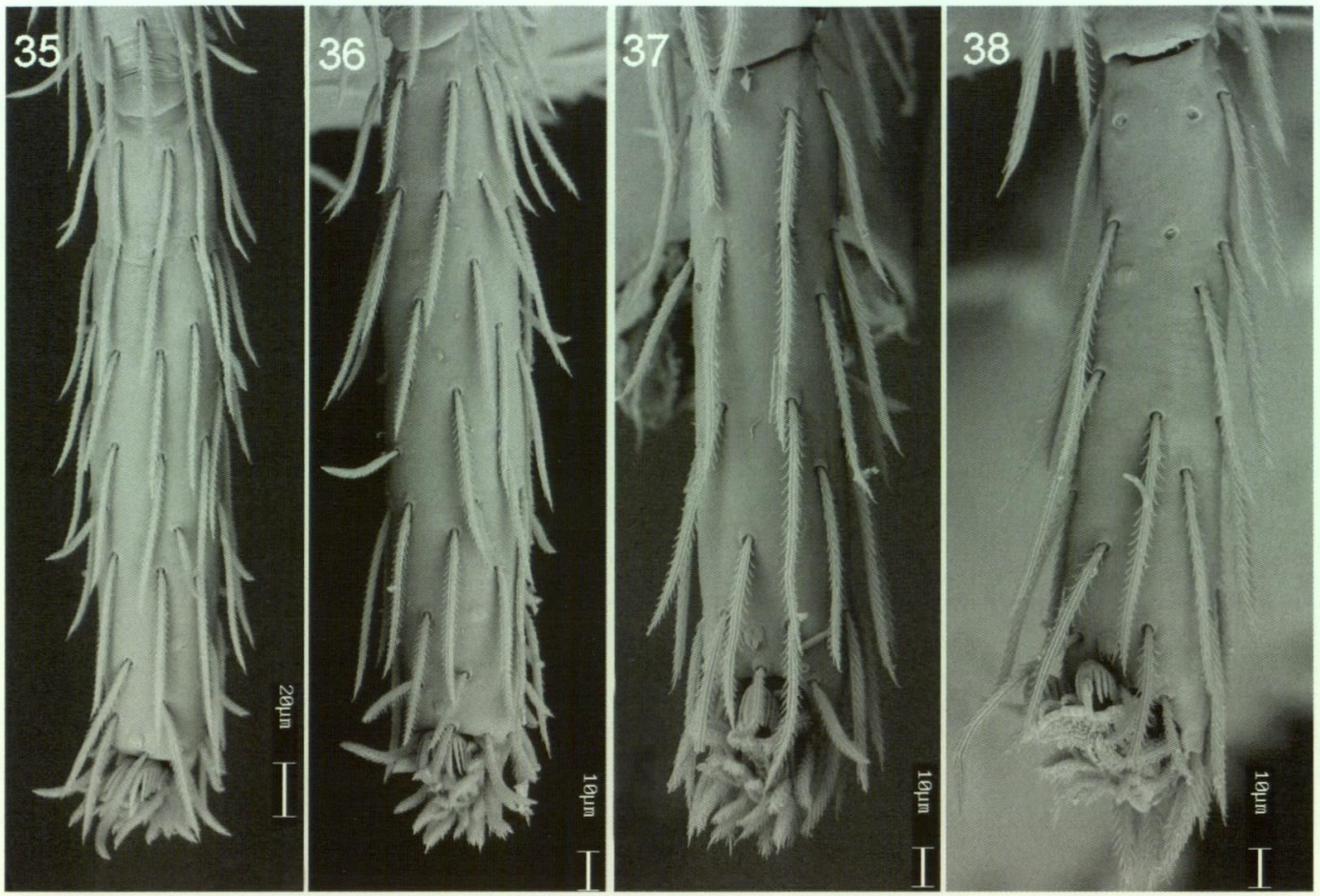

Figures 35-38 Hickmanolobus linnaei sp. nov., male, tarsi I-IV: 35, leg I; 36, leg II; 37, leg III; 38, leg IV.
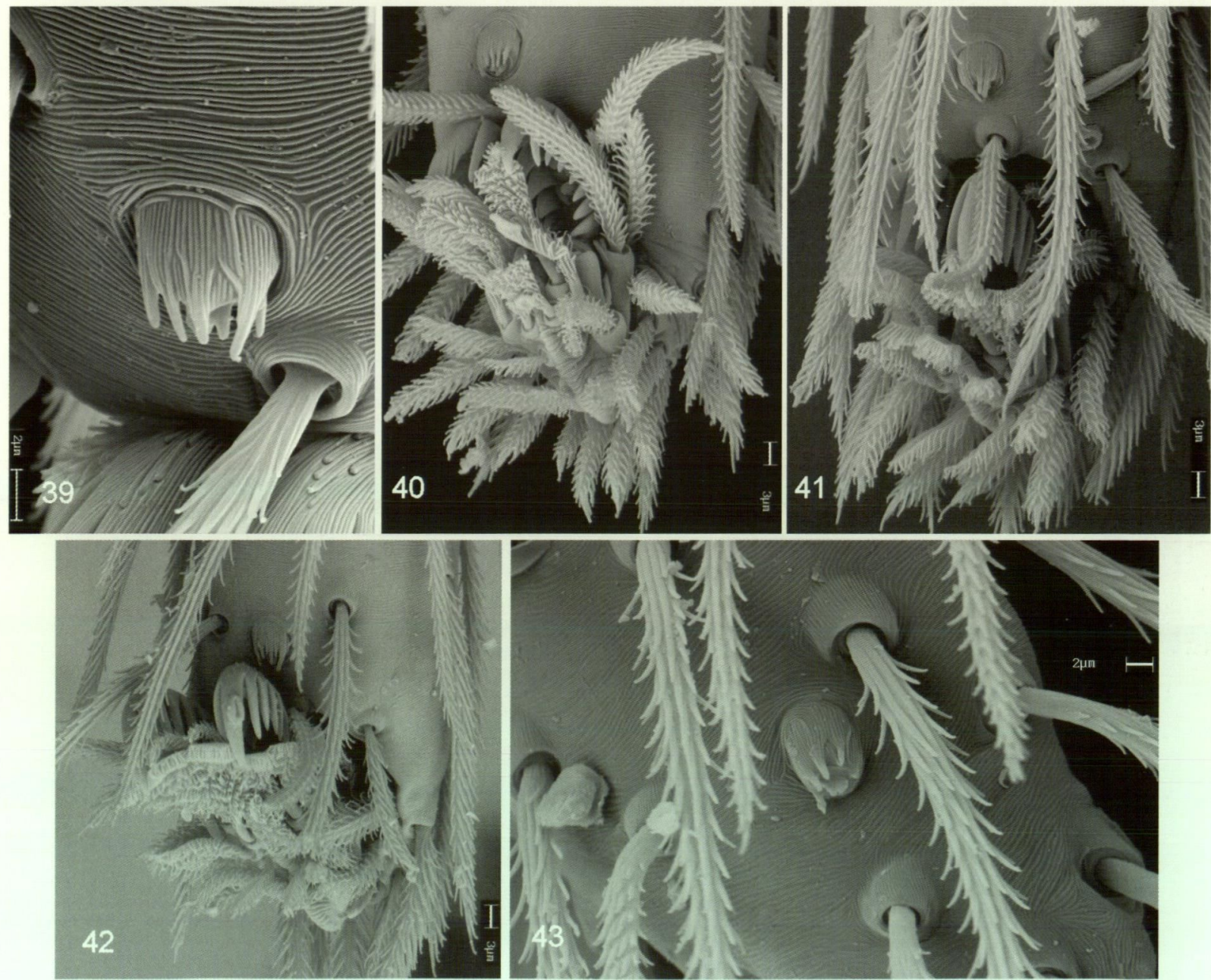

Figures 39-43 Hickmanolobus linnaei sp. nov., male, tarsal organ: 39, leg I; 40, leg II; 41, leg III; 42, leg IV; 43, cymbium. 


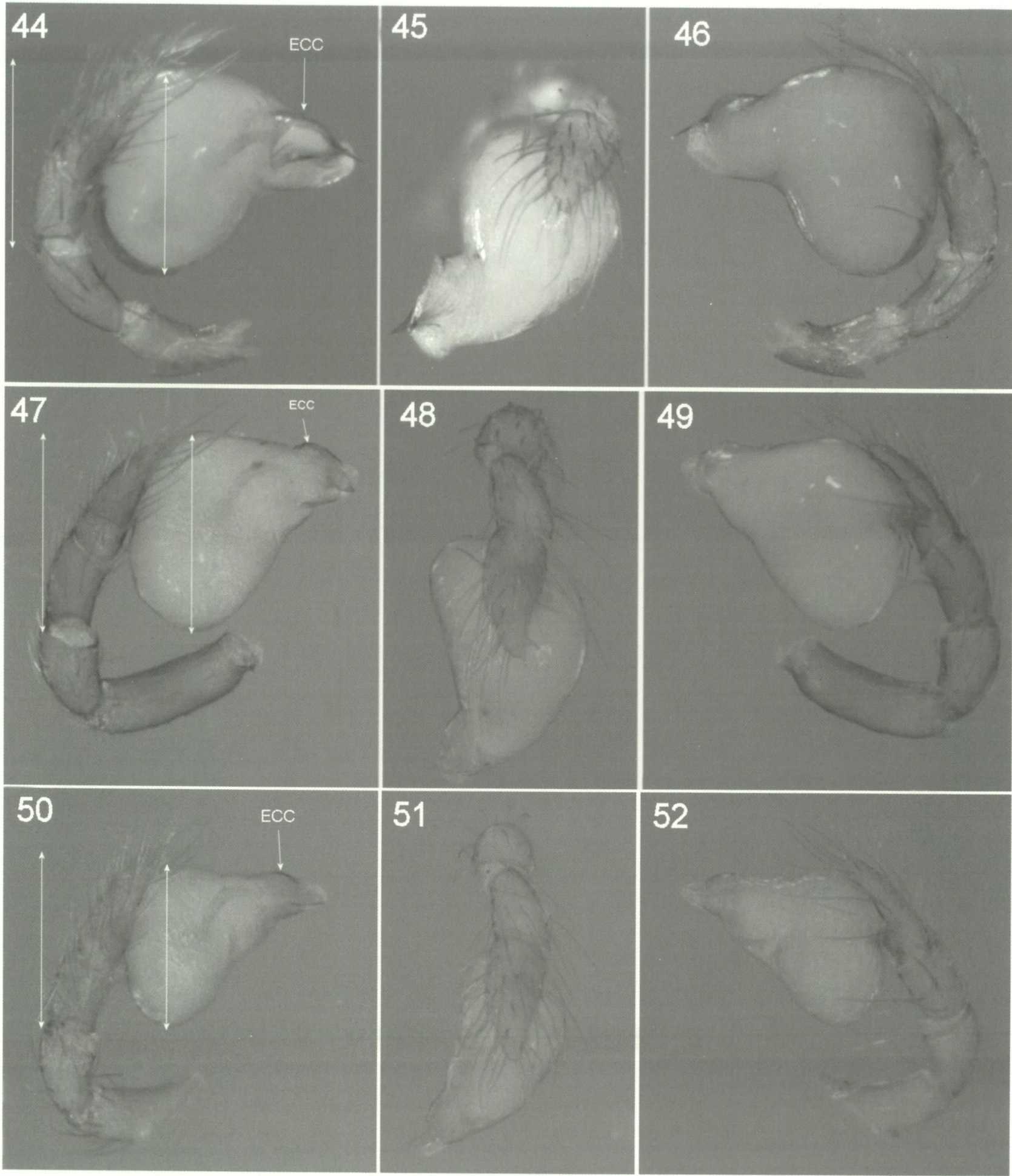

Figures 44-52 Hickmanolobus, palps: 44, 47, 50, prolateral view; 45, 48, 51, dorsal view; 46. 49, 52, retrolateral view; 44-46: Hickmanolobus ibisca sp. nov.; 47-49, Hickmanolobus linnaei sp. nov.; 50-52: Hickmanolobus jojo sp. nov. 

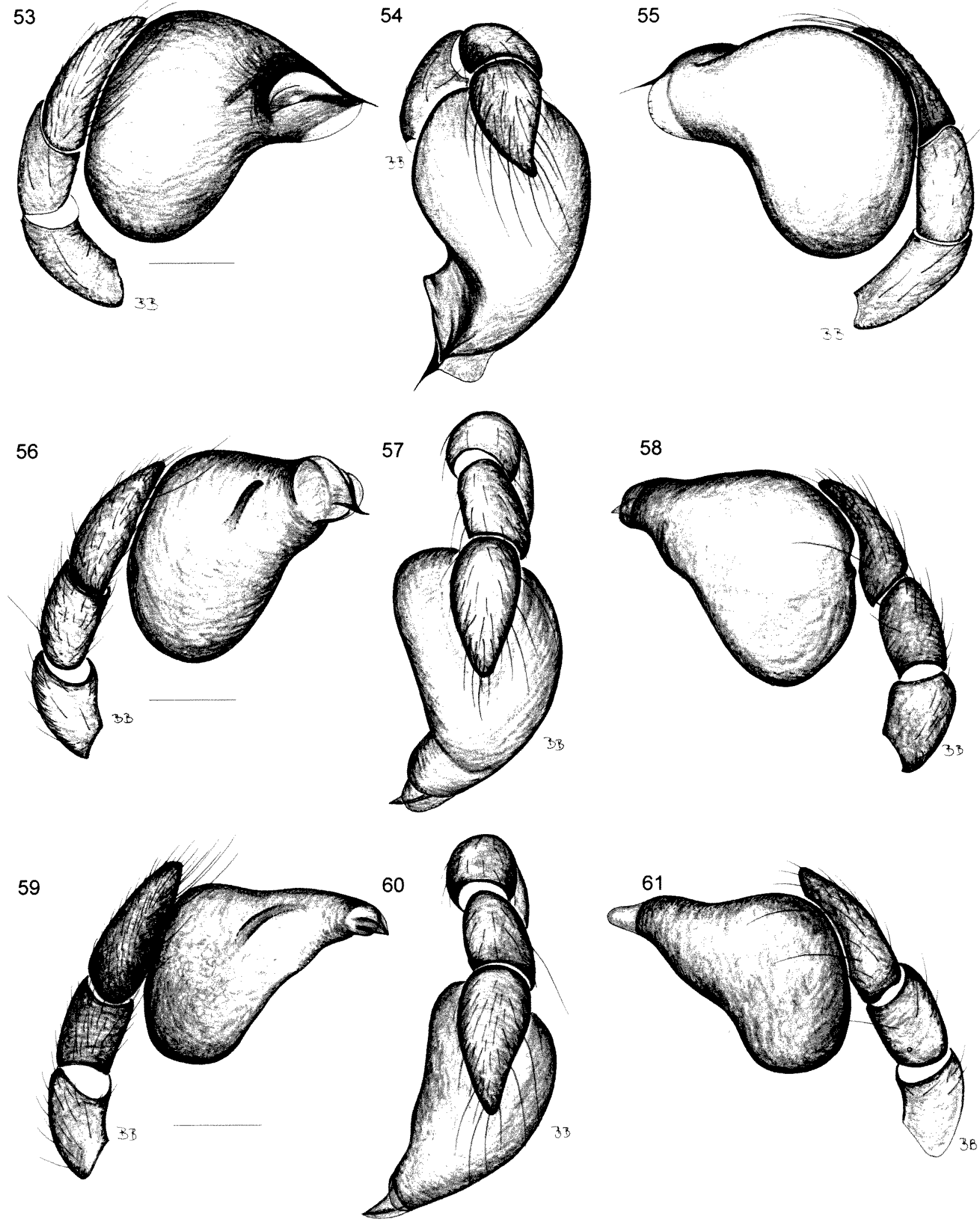

Figures 53-61 Hickmanolobus, palps: 54, 56, 59, prolateral view; 54, 57, 60, dorsal view; 55. 58, 61, retrolateral view; 53-55, Hickmanolobus ibisca sp. nov; 56-58, Hickmanolobus limaci sp. nov.; 59-61: Hickmanolobus jojo sp. nov. Scale lines $=0.1 \mathrm{~mm}$. 


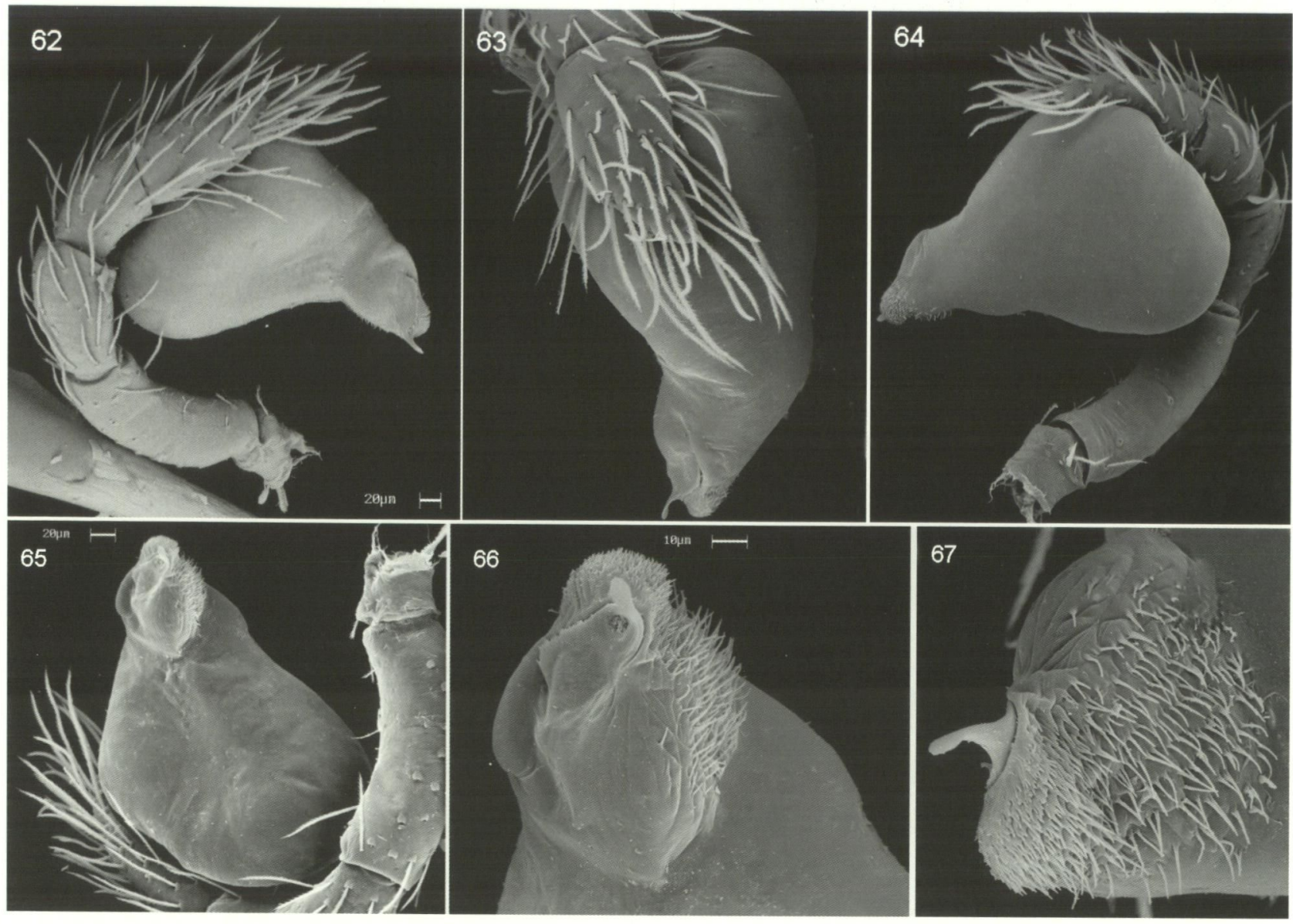

Figures 62-67 Hickmanolobus linnaei sp. nov., male, palp: 62, prolateral view; 63, dorsal view; 64, retrolateral view;65, palp, ventral view; 66, embolar complex, ventral view; 67, embolus, retrolateral view.

Hickmanolobus ibisca sp. nov.

Figures 3, 4, 8, 9, 13, 14, 18, 19, 44-46, 53-55, 69, 70, $73-75$

Material examined

\section{Holotype}

Australia: Queensland: $\widehat{\text { Q }}$, Lamington National Park, IBISCA Old Plot\# IQ 700-B, 775 m, 28¹9'S, $153^{\circ} 12^{\prime} \mathrm{E}, 2-6$ October 2006, rainforest, B. Baehr, K. Staunton, pitfall trap (QM S81126, PBI_OON_ 00006345).
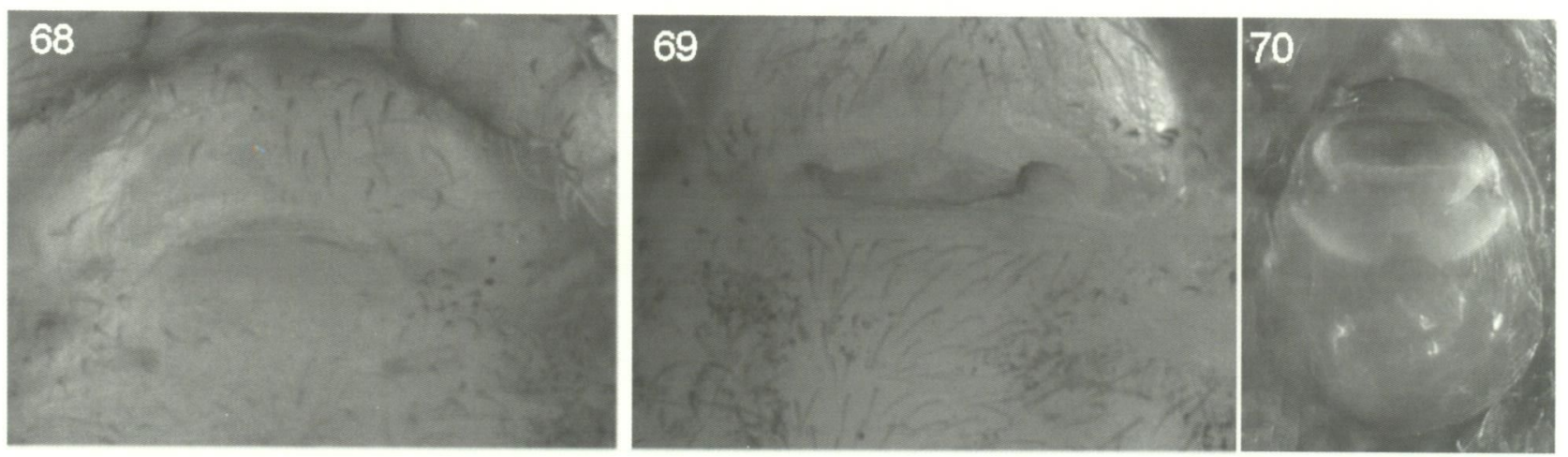

Figures 68-70 Hickmanolobus, female genitalia: 68, Hickmanolobus linnaei sp. nov., female epigyne, ventral view; 69-70,
Allotype

Australia: Queensland: $q$, same locality as holotype (QM S55526, PBI_OON_00022897).

\section{Other material examined}

Australia: Queensland: 1 \%, same as holotype but IQ 700C, 11-20 October 2006, K. Staunton (QM S81069, PBI_OON_00006344); 1 ô, same as holotype but IQ 700 D (QM S81119, PBI OON_00022718). New South Wales: 1 ô, Cherry

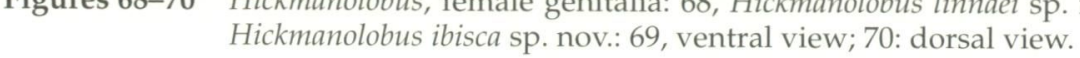



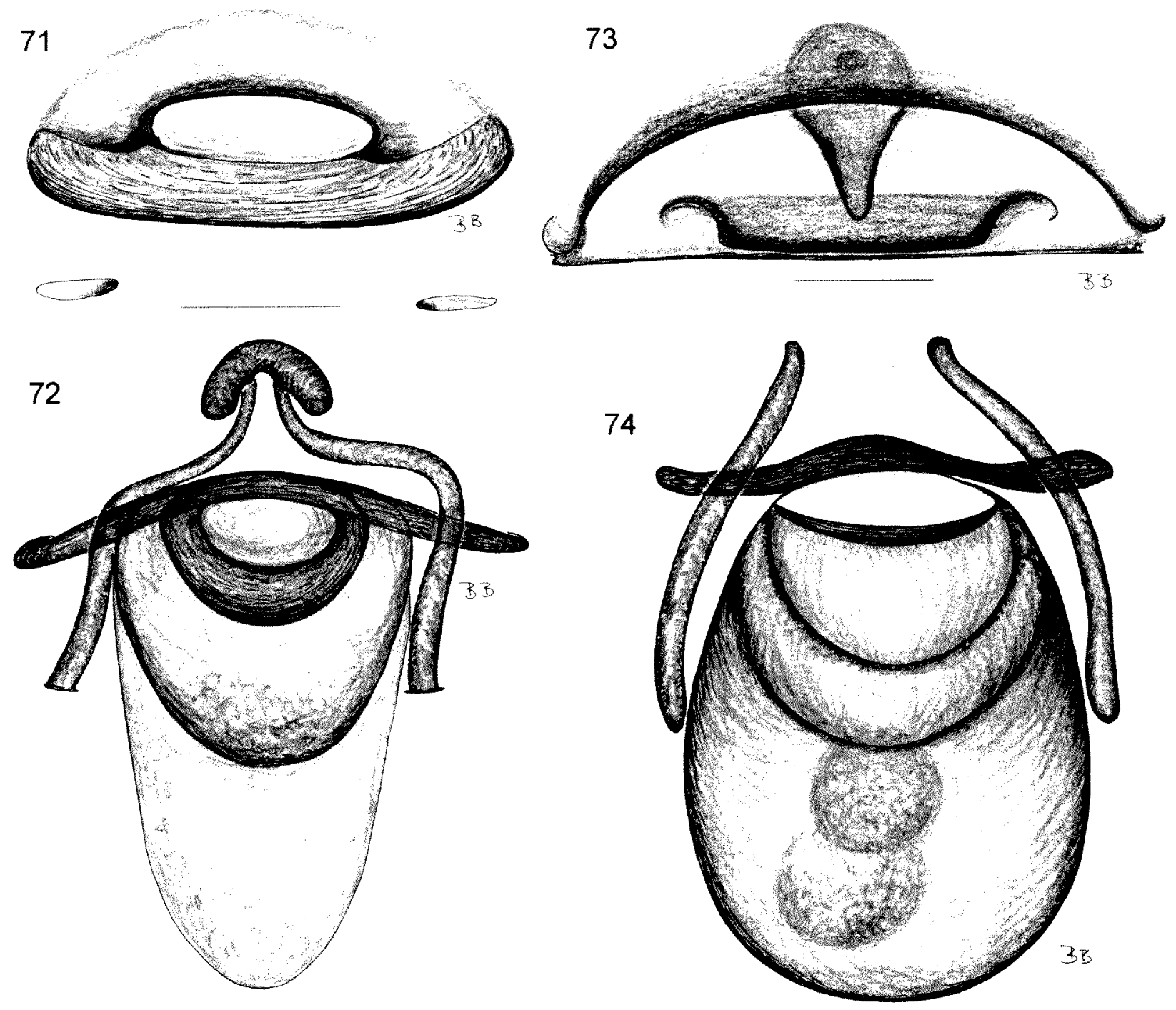

Figures 71-74 Hickmanolobus, female genitalia: 71-72, Hickmanolobus linnaei sp. nov, female epigyne: 71, ventral view; 72, dorsal view; 73-74, Hickmanolobus ibisca sp. nov., female epigyne: 73, ventral; 74, dorsal. Scale lines = $0.1 \mathrm{~mm}$.

Tree North State Forest, $400 \mathrm{~m}, 28^{\circ} 54^{\prime} \mathrm{S}, 152^{\circ} 45^{\prime} \mathrm{E}$, rainforest, April-May 1976, M. Gray, C. Horseman, pitfall trap (AM KS10314, PBI_OON_00020230).

\section{Diagnosis}

The male palpal bulb and secondary lobe resemble that of $H$. mollipes, but the embolus is short and almost straight; compared to $H$. linnaei the male bulb is bigger, width of bulb (measured basally) is greater than cymbium and tibia combined (Figure $44, \leftrightarrow$ ); the embolus conductor complex is wider than in H. linnaei (Figures 45, 54). Females can be separated from $H$. mollipes and H. linnaei by the abdominal colour pattern (female of $H$. jojo unknown); epigynum with $v$-shaped projection.

\section{Description}

\section{Male}

Total length 1.42. Carapace 0.62 long, 0.51 wide, caput width 0.29 ; abdomen 0.80 long, 0.41 wide. Carapace yellow-brown, with dark purple reticulate pattern (Figure 3), sternum, chelicerae, endites and labium yellow-brown, slightly mottled with dark purple. Abdominal dorsum dark purple with one pale inverted $\mathrm{v}$-shaped chevron; venter centrally paler, margin dark purple. Legs yellow-brown. Palpal bulb (Figures 44-46, 53-55) bulbously pear-shaped, basally wider than tibia and cymbium length combined. Embolus needlelike, sharply pointed, secondary lobe broad, probably covered with tiny spicules. 


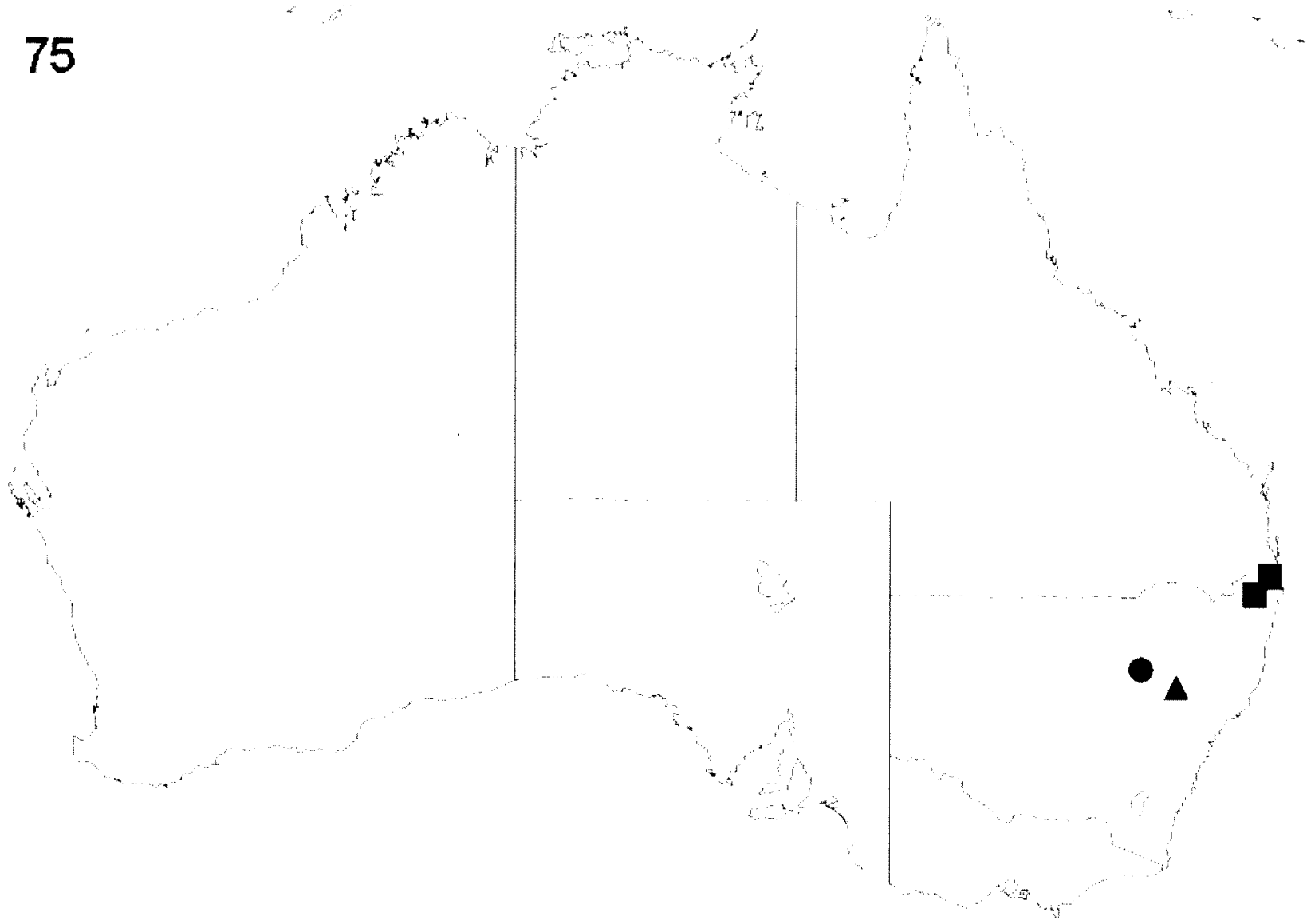

Figure 75 Distribution of the genus Hickmanolobus from mainland Australia: H. ibisca sp. nov H. jojo sp. now.

\section{Female}

Total length 1.72. Carapace $0.66 \mathrm{long}, 0.52$ wide, caput width 0.28 ; abdomen 1.06 long, 0.65 wide. Coloration as in male. Epigastric fold (Figures 69, $70,73,74)$ anteriorly broadly oval with posteriorly directed, v-shaped projection, posterior margin with rectangular sclerite, internal female genitalia with with large globular posterior receptaculum divided into three compartments. Tracheal system consists of two simple tubes directed forward through the pedicel (Figure 74).

\section{Distribution}

This species occurs in rainforests near the border of New South Wales and Queensland (Figure 75).

\section{Etymology}

The specific name is a patronym in honour of Ibisca Queensland (Investigating the Biodiversity of Soil and Canopy Arthropods). Ibisca Queensland, initiated by Roger Kitching from Griffith University, is a joint initiative of the Smithsonian Institute, the Queensland Museum,
Queensland Herbarium, Queensland National Parks and Wildlife Service, Global Canopy Programme, National Parks Association of Queensland and SEQ Catchments, with additional support from the Queensland Government through its Smart State Innovation Projects Fund.

\section{Hickmanolobus jojo sp. nov.}

Figures 5, 10, 15, 20, 50-52, 59-61,75

\section{Material examined}

Holotype

Australia: New South Wales: $b$. Warrumbungles Range, Siding Springs Road, 0.9 $\mathrm{km}$ from observatory, $31^{\circ} 16^{\prime} 15^{\prime \prime} \mathrm{S}, 149^{\circ} 04^{\prime} 31^{\prime \prime} \mathrm{E}, 10-24$ November 2001, M. Gray, G. Milledge, H. Smith, pitfall trap (AM KS75447, PBI_OON_00020564).

\section{Diagnosis}

Males resemble those of $H$. limati but the palpal bulb is more slender; width of bulb (measured basally) is shorter than cymbium and tibia combined (Figure 50); the embolus conductor complex is narrower than in H. limme?. 


\section{Description}

Male

Total length 1.43. Carapace 0.66 long, 0.49 wide, caput width 0.28; abdomen 0.77 long, 0.51 wide. Carapace, sternum, chelicerae, endites and labium yellow-brown. Abdominal dorsum dark purple with one pale, inverted $v$-shaped chevron, followed by about three obscure, more horizontal chevrons (Figure 5); venter dark purple, only epigastric area pale (Figure 10). Legs yellow-brown. Palpal bulb (Figures 50-52, 59-61) pear-shaped, basally shorter than tibia and cymbium length combined. Invagination holding the embolus conductor complex small, embolus triangular with pointed tip, conductor membranous, scooped, small secondary lobe probably covered with tiny spicules.

\section{Fenale}

Unknown.

\section{Distribution}

This species is only known from the Warrumbungles Range of New South Wales (Figure 75).

\section{Etymology}

The generic name is an arbitrary combination of letters.

\section{ACKNOWLEDGEMENTS}

We would like to thank Norman Platnick who spotted that these spiders were in fact orsolobids, and not oonopids. This paper is dedicated to people and institutions who encourage and support taxonomic science. This paper would not have been completed without the support of the National Science Foundation's PBI (Planetary Biodiversity Inventory) program provided through grant DEB-0613754. We thank Graham Milledge (Australian Museum, Sydney), Robert Raven, Owen Seeman and Wendy Hebron (Queensland Museum, Brisbane) for loan of the material and great support for the work. SEM images were taken by Sue Lindsay (Australian Museum Scanning Electron Microscopy and Microanalytical Unit). Last we would like to thank Johanna Baehr, daughter of the of senior author, who assisted passionately in databasing the identified collections of the Australian Museum, the Queensland Museum and the ANIC collection (Canberra) for the goblin spider PBI project and this orsolobid project, as well as Ursula Baehr for being patient.

\section{REFERENCES}

Forster, R.R. and Forster, L. (1999). Spiders of New Zealand and their Worldwide Kin. University of Otago Press: Dunedin.

Forster, R.R. and Platnick, N. I. (1985). A review of the austral spider family Orsolobidae (Arachnida, Araneae), with notes on the superfamily Dysderoidea. Bulletin of the American Museum of Natural History 181: $1-229$.

Griswold, C.E. and Platnick, N. I. (1987). On the first African spiders of the family Orsolobidae (Araneae, Dysderoidea). American Museum Novitates 2892: 1-14.

Hickman, V. (1932). Studies in Tasmanian Spiders. Part V. Papers and Proceedings of the Royal Society of Tasmania 1931: $20-31$.

Hickman, V. (1979). Some Tasmanian Spiders of the Families Oonopidae, Anapidae and Mysmenidae. Papers and Procedings of the Royal Society of Tasmania 113: $53-79$.

Platnick, N. I. and Brescovit, A. D. (1994). A new genus of the spider family Orsolobidae (Araneae, Dysderoidea) from Brazil. American Museum Novitates 3112: 1-6.

Manuscript received 31 March 2008; accepted 8 July 2008. 